\title{
A Pluralistic Reading of the First Amendment and Its Relation to Public Discourse
}

\author{
Paul G. Stern
}

In the last twenty years or so, the political interpretation of the free speech clause, most clearly defended by Alexander Meiklejohn, has come to occupy a central position in discussion of the First Amendment, both within academic circles and in the jurisprudence of the Supreme Court. ${ }^{1}$ This is not to say that this paradigm has won universal acceptance. Rather, it has attracted a wide spectrum of critics, who charge that the theory is either too narrow in scope, ${ }^{2}$ or overly instrumental in form, ${ }^{3}$ or inappropriately consequentialist in its scheme of justification."

The principal aim of this Note is to assess the significance these attacks on the political interpretation of speech have for a proper understanding of the First Amendment. The Note advances an alternative theory of free speech that seeks to take account of the defects of the political approach while retaining its central insight: namely, that our protection of free speech is grounded in its function of sustaining a framework of unconstrained public discourse in which agents can deliberatively define their purposes by reciprocally weighing the merits of opposing positions.

Section I surveys three competing accounts of free speech and argues that the political approach offers the most promising starting point for elaborating a coherent theory. Section II criticizes Meiklejohn's political interpretation of the free speech clause and establishes the need to expand his conception of public discourse to incorporate the end of deliberative self-definition as a complement to that of democratic self-government. Section III elucidates the way in which the discourse model clarifies the special constitutional status of speech. Finally, Section IV explores the impli-

1. See A. Meiklejohn, Political Freedom (1960) (expanded version of A. Meiklejohn, Free Speech and Its Relation to Self-Government (1948)). In a recent article Lee Bollinger referred to this conception as the "Sullivan-Kalven-Meiklejohn paradigm," which emerged in the mid-1960's and continues to exert a pervasive influence on discussion of the theoretical underpinnings of the First Amendment. See Bollinger, Free Speech and Intellectual Values, 92 YALE L.J. 438, 439 (1983).

2. See, e.g., Baker, Scope of the First Amendment Freedom of Speech, 25 UCLA L. REV. 964 (1978); Redish, The Value of Free Speech, 130 U. PA. L. Rev. 591 (1981).

3. See, e.g., L. TRIBE, AmERICan Constitutional LAw $\S 12-1$, at 785-89 (1988).

4. See, e.g., R. Dworkin, A MAtrter of Principle 385-93 (1985); Richards, A Theory of Free Speech, 34 UCLA L. REv. 1837, 1893-95 (1987). 
cations of this approach for the Court's recent adjudication of some difficult free speech problems.

\section{Competing Accounts of SpeEch}

The free speech clause of the First Amendment serves as the centerpiece of a range of constitutional protections securing our basic civil and political liberties. Far less apparent is the precise scope and significance of the liberties it protects. Interpretive difficulties arise here not only because it is hard to say exactly what forms of speech are covered by the prohibition of Congressional restrictions on freedom of expression, but also because there does not appear to be any clear historical evidence that the Framers themselves entertained either a coherent or recognizably familiar theory of freedom of speech. ${ }^{\boldsymbol{5}}$

Nor does the tradition of constitutional interpretation of the clause, particularly in the decisions of the Supreme Court since Schenck v. United States $^{6}$ in 1919, speak in a univocal voice on the matter. Even if one takes into account only the famous dissents (or dissenting concurrences) of Justices Holmes and Brandeis and the later influential opinions of Justice Brennan in cases such as New York Times $v$. Sullivan, ${ }^{7}$ it would be very difficult to extract an internally consistent and systematic theory of freedom of expression that organizes our intuitions about what counts as speech worthy of protection.

Still, the tradition of judicial interpretation does narrow the range of possible answers. Broadly speaking, there are three different approaches that have oriented both the Court and contemporary legal theorists in their attempts to identify those distinctive features of speech that warrant special constitutional protection.

\section{A. Three Models of Speech}

According to the first view, freedom of speech must be understood as an inviolable "negative liberty" that is protected by an absolute right to individual self-expression. Freedom of expression serves here primarily as an "opportunity-concept": It is the freedom to say (or not to say) whatever one wants, irrespective of content or context, to affirm whatever beliefs

5. Indeed, the passage of the Sedition Act in 1798, only seven years after the adoption of the Bill of Rights, suggests that there was hardly an initial consensus as to whether the First Amendment is designed to protect speech sharply critical of the government from the imposition of criminal sanctions, including imprisonment. Leonard Levy argues that "neither the Revolution nor the First Amendment superseded the common law by repudiating the Blackstonian concept that freedom of the press meant merely freedom from prior restraint." L. LEvy, Constrrutional Opinions 162 (1986). This implies in particular that there was no repudiation of the concept that the government may be criminally assaulted merely by the expression of critical opinions about its performance. In this connection, see also H. Kalven, A Worthy Tradition 63-68 (1988).

6. 249 U.S. 47 (1919).

7. 376 U.S. 254 (1964). 
and attitudes one chooses. The idea is that one's beliefs, opinions and attitudes are distinctively one's own, much like one's own body or personal property. The state's attempts to interfere with expression of one's beliefs is, therefore, a violation of one of the most basic prerogatives of personal liberty. ${ }^{8}$

The second conception characterizes freedom of speech in more positive terms as a distinctive domain of self-actualization. On this view individuals cultivate a sense of themselves and their values through exercising the liberty of self-expression. Here the scope of the liberty is more limited than that warranted by the first model: Only those forms of speech that somehow promote the values of self-development or self-actualization merit protection. This view also tends to stress the importance of exposure to divergent forms of self-expression as a condition of full selfdevelopment. ${ }^{\circ}$

The third model conceives of freedom of speech as a condition of our exercise of political liberty. That is, we enjoy freedom of speech only insofar as it is necessary for us to carry out the function of self-government, to serve as members of a community of common political deliberation: "The First Amendment does not protect a 'freedom to speak.' It protects the freedom of those activities of thought and communication by which we 'govern.' "'10

In recent discussion of First Amendment theory, this third perspective has acquired a certain pre-eminence that is partly due to superior clarity. ${ }^{21}$ In contrast, the defects of the first two approaches are readily apparent. The first view construes the free speech clause as excluding governmental restraint of all expressive activities and thus ignores the many ordinary contexts in which the government imposes constraints on speech

8. This conception of freedom of expression is invoked with powerful effect in two often-cited cases in which it is alleged that the state tried to compel individuals to affirm beliefs they did not hold. West Virginia Bd. of Educ. v. Barnette, 319 U.S. 624 (1943); Wooley v. Maynard, 430 U.S. 705 (1977).

9. This idea underlies Holmes' recommendation in Abrams v. United States, 250 U.S. 616,630 (1919) (Holmes, J., dissenting), that we must suspend absolute faith in "the very foundations of [our] own conduct" and subject our views to the test of "free trade in ideas." It also plays a part in Brandeis' claim in Whitney v. California, 274 U.S. 357, 375 (1927) (Brandeis, J., concurring) that free speech must be protected because "It]hose who won our independence believed that the final end of the state was to make men free to develop their faculties." The function of speech in promoting the values of individual self-realization and self-fulfillment is emphasized in T. EMERSON, THE SySTEM OF FREEDOM OF EXPRESSION 6 (1970), and has more recently served as the fundamental principle for free speech theorists such as Martin Redish and C. Edwin Baker. See M. REDISH, FreEdom of ExPRESSION: A Critical ANalysis (1984); Baker, supra note 2.

10. Meiklejohn, The First Amendment Is an Absolute, 1961 SUP. CT. REv. 245, 255; see also A. MEIKLEjoHn, supra note 1, at 26 ("The First Amendment, then, is not the guardian of unregulated talkativeness .... What is essential is not that everyone shall speak, but that everything worth saying shall be said.")

11. It has the virtue, as Harry Kalven has noted, of assigning the First Amendment a "central meaning" anchored in the purposes of our republican system of government. It provides a clear answer to the question of which forms of speech are covered under this amendment and why they warrant such unconditional protection. See Kalven, The New York Times Case: A Note on "The Central Meaning of the First Amendment," 1964 Sup. CT. REv. 191. 
without raising any serious First Amendment concerns, such as regulation of speech related to economic activity, prohibition of unruly conduct, and decrees against slander, libel, and conspiracy to commit crimes. In other words, this view fails to address the need to formulate some criterion of relevance distinguishing that domain of our liberty that qualifies as "freedom of speech" from other expressive activities not covered by this clause. The second model faces this demand, but remains too inclusive. There are many speech acts, after all, that might be construed as promoting one's self-actualization (for example, engaging in betting, fraud, or extortion), but are surely not protected under the First Amendment. More importantly, the promotion of perfectionist ends is not a function that applies exclusively to speech. We can realize our potential or perfect our talents by pursuing a wide range of non-communicative activities. ${ }^{12}$

But the political interpretation of the free speech clause is also defective. The type of speech covered by promoting the principal end of selfgovernment fails to accord with our common understanding of the wide spectrum of expression worthy of protection, and thus this model fails to provide a sufficiently comprehensive foundation for a theory of free speech. ${ }^{13}$

\section{B. The Standpoint of Current Theory}

For some critics this objection marks a fatal weakness in the political account of speech. Consequently, they either renounce a unified theory altogether in favor of an eclectic view ${ }^{14}$ or seek refuge in an alternative systematic principle, such as toleration, self-realization, or minimizing the harms of state intervention. ${ }^{16}$ In so doing, however, they fail to take full measure of the most important advance marked by the political interpretation of the First Amendment: namely, its recognition that our commitment to freedom of expression is anchored in its promoting a public framework of discourse in which unrestricted common deliberation on matters of mutual interest is secured from the arbitrary intrusion of state power.

If we restrict our attention to the relationship between the solitary individual and his linguistic expressions, we cannot explain either the scope of

12. This argument is developed at greater length in Schauer, Must Speech Be Special?, $78 \mathrm{Nw}$. U.L. REv. 1284, 1289-93 (1983).

13. The proponents of the political interpretation have tried to meet this objection by exploiting the sense in which certain non-political forms of expression (such as art and literature) indirectly promote our appreciation of political values. However, as we shall see in Section II, this strategy is unconvincing.

14. See, e.g., Alexander \& Horton, The Impassibility of a Free Speech Principle, 78 Nw. U.L. REv. 1319 (1983); Cass, The Perils of Positive Thinking: Constitutional Interpretation and Negative First Amendment Theory, 34 UCLA L. REv. 1405 (1987); Farber \& Frickey, Practical Reason and the First Amendment, 34 UCLA L. REV. 1615 (1987).

15. See, e.g., L. Bollinger, The Tolerant Society: Freedom of Speech and Extremist SPeECH in AMERICA (1986); M. Redish, supra note 9; F. Schauer, Free SpeECh: A PhilosophICAL ENQUIRY (1982). 
our First Amendment liberties or their underlying rationale. This is precisely the common problem with the first two approaches. In contrast, the political interpretation understands the speech protected by the First Amendment principally within the context of a field of communicative interaction in which agents are engaged in public discussion of their most fundamental values, beliefs, and attitudes. The protection afforded expression in this context is designed to ensure that the outcome of this conversation will be determined by the persuasiveness of the reasons agents themselves adduce in support of their values and beliefs, not by the dictates of arbitrary power or prejudice sponsored by the state. ${ }^{16}$

But the difficulty with the exclusively political approach to the free speech clause is that this idea is worked out within a systematic perspective too narrow to encompass all those forms of expression we regard as worthy of constitutional protection. We need to expand this idea of public discourse to include not only speech that is necessary to advance the process of self-government, but also speech that is necessary to advance the process of individual self-definition. We engage in such public discussion not only about matters of common political interest central to the project of self-government, but also about matters of overlapping individual interest having to do with the persuasiveness of those religious, philosophical, moral, aesthetic, and personal ideals that shape the contours of our own self-conceptions. The end of this discourse is not to master the collective challenge of governing a democratic polity but to master the individual challenge of governing ourselves, that is, to define deliberatively those values, ideals and conceptions of the good that set the terms by which each of us organizes his own life. We single out certain forms of expression (for example, scientific-philosophical, literary, and aesthetic expression) for special constitutional protection because only by so doing can the integrity and independence of this debate be secured from arbitrary state intrusion in a way that parallels the independence of political debate.

This Note aims to defend a two-pronged conception of public discourse that provides a suitably comprehensive framework for understanding the full range of expressive activities that we regard as entitled to protection under the free speech clause. This model captures the insights of the second and third approaches identified above. But in contrast to the second approach, the protection of expressive speech is grounded in the need to promote a "public sphere" of unrestricted debate in which citizens can deliberatively define both their collective and individual purposes. ${ }^{17}$

16. Affirmation of the value of free speech is, as Brandeis eloquently remarked in his concurrence in Whitney v. California, 274 U.S. 357, 375 (1927), inseparable from "[b]elieving in the power of reason as applied through public discussion . . .."

17. This idea of a framework of public discourse lends a more lucid formulation to the "marketplace of ideas" metaphor that has haunted the rhetoric of the Court from Holmes to Brennan. For an interesting discussion of the subtle changes in meaning effected in the shift from Holmes' metaphor of "free trade in ideas" to Brennan's invocation of the "marketplace of ideas," see Cole, Agon at Agora: 


\section{A Critique of the Political View and Expansion of the MODEL}

\section{A. The Limits of Public Speech}

There is an arresting simplicity to the contention that the protection of speech afforded by the First Amendment is grounded in the political imperatives of self-government. As Meiklejohn argues, we need to specify some "rational principle" that will allow us to demarcate the range of expressive liberties falling under the absolute protection of the First Amendment. This principle can be found in the fundamental choice of the people, embodied in the Constitution, to submit to a system of government in which they retain the ultimate basis of authority. It follows that the government cannot deny the people the right to express and hear those political ideas, attitudes, or beliefs that they choose because to do so would be to interfere with their responsibility as citizens to govern themselves. Their assumption of this responsibility requires that they enjoy unrestricted access to whatever ideas, points of view, or information may prove necessary to make intelligent decisions about governing matters.

Meiklejohn is careful to extend this special First Amendment protection only to speech related to the end of political self-government. He distinguishes this speech from a more limited, "private" liberty of speech that is subject to abridgment under the due process clause of the Fifth Amendment, a liberty he characterizes as "the right to speak one's mind as one chooses ...."18

Meiklejohn's argument for reserving First Amendment protection solely to public speech concerning political matters is: (1) that under Article One, section six, the Constitution affords "absolute protection" to the speech of our political representatives, and as representatives derive their governing power from citizens, the latter must enjoy at least as much protection as their elected agents; ${ }^{19}$ and (2) that the provisions of the First Amendment must be interpreted "in relation to the intention and structure of the Constitution as a whole,"20 and thus the protection of speech must be understood in light of the fundamental constitutional end of establishing a republican system of government.

But this argument is inadequate. While it is undeniable that one of the intentions inscribed in the Constitution is to establish a republican system of government, this is surely not the sole or even the overriding intention. Meiklejohn appeals to the Preamble as an important interpretive re-

Creative Misreading in the First Amendment Tradition, 95 YAL.E L.J. 857, 886, 894 (1986).

18. A. Meiklejohn, Political Freedom, supra note 1, at 37.

19. "The freedom which we grant to our representatives is merely a derivative of the prior freedom which belongs to us as voters." Id. at 36 .

20. Meiklejohn, supra note 10, at 253. 
source, ${ }^{21}$ and this states that the Constitution is designed to "secure the Blessings of Liberty to ourselves and our Posterity." But the "Blessings of Liberty" include not merely the political liberty to participate in collective self-government; they also include the individual liberty to define the fundamental ends and purposes of one's own life in the absence of unwarranted intrusion. To this Meiklejohn would respond that it is only the Second through Ninth Amendments that are devoted to ensuring that "due regard shall be paid to the private 'rights of the governed.' "In contrast, he argues, "The First and Tenth Amendments protect the governing 'powers' of the people from abridgment by the agencies which are established as their servants." 22

But the first clause of the First Amendment does not have to do primarily with protection of the people's governing powers, but with the right of each person to worship freely in accordance with his own religious convictions. ${ }^{23}$ This clause most emphatically does not protect a nationally defined public liberty or governing power, since its purpose is to set the prescription of preferred forms of religious worship entirely outside the province of the legislative power and to secure the free exercise of religious liberty from governmental intrusion. It is thus inaccurate to characterize the First Amendment as concerned exclusively with the protection of public liberties or governing powers. There is every reason to think that in extending immunity from legislative abridgment to free speech it is not only speech's public function of promoting self-government, but also its private function of promoting the liberties of thought and conscience that is entitled to full protection. ${ }^{24}$ On the continuum of private and public liberties designated in the First Amendment, freedom of speech stands somewhere in the middle-that is, somewhere between freedom of religious worship and freedom to petition the government for a redress of grievances. ${ }^{25}$

Meiklejohn's reading of the First Amendment evinces a distinct preference for the liberties of the ancients, to use Benjamin Constant's phrase, over the liberties of the moderns. On his conception, the citizen's liberty to

\footnotetext{
21. Id.

22. Id. at 254.

23. "Congress shall make no law respecting an establishment of religion, or prohibiting the free exercise thereof . . . ." U.S. ConsT. amend. I, cl. 1.

24. D.A.J. Richards calls attention to the fact that in the Report on the Virginia Resolutions Madison himself argued that the liberties of religious conscience and freedom of speech had to be conceived as essentially linked. See Richards, supra note 4, at 1873.

25. At least part of the reason that Meiklejohn may be inclined to segregate "public" and "private" speech in this way and to relegate "private speech" to the weaker protection of the Fifth Amendment is that he tends to identify private speech with expression that is selfishly or commercially motivated. But someone who expresses himself about matters of fundamental personal conviction relating, for example, to his moral or religious ideals is not engaged in public speech for the common welfare but at the same time is not motivated by selfish, egoistic concerns. Rather, he is engaged in public discourse about individual ideals, and the purpose of this discourse is to advance the deliberative self-definition of the agents who participate in it.
} 
participate actively in common deliberation about shared public goods has priority over what he terms the merely "private" rights of the individual to exchange views with others on matters of fundamental personal conviction. The First Amendment, however, will not support such a partial construal of its meaning: The conception of liberty it invokes bridges the dividing line separating private from public autonomy. ${ }^{26}$

\section{B. The Problem of Scope and Rationale}

Nor is it clear that the exclusively political approach will succeed in extending the shield of First Amendment protection to all those forms of expression we regard as worthy of it. In particular, scientific, literary, philosophical, and artistic forms of expression appear to be in an especially vulnerable position, as they do not evidence any noticably direct relation to the protected domain of speech, that is, to public discussion of matters pertaining to political self-government. ${ }^{27}$

Meiklejohn tries to address this problem by insisting that ostensibly non-political forms of communication whose free expression we value, such as science, philosophy, art, and literature, are also entitled to protection under his principle because they promote "the knowledge, intelligence, sensitivity to human values . . . which, so far as possible, a ballot should express." ${ }^{28}$ The problem with this "indirect" method of justifying the extension of protection is that, as Bork points out, it is indiscriminately broad in principle. ${ }^{29}$ There are many different experiences and social relationships that contribute to our appreciation of political values and to the development of our ability to exercise reasoned judgment in political affairs. But it would be implausible to argue that for this reason the First Amendment exempts all speech (or, more broadly, symbolic con-

26. In this respect the reading of the First Amendment advanced here diverges from that elaborated by D.A.J. Richards. See D.A.J. Richards, TOleration AND the Constitution (1986); Richards, supra note 4. Richards thinks that the background right underlying the free speech guarantee is "the right to conscience, interpretively central to religion clause jurisprudence." D.A.J. RrCHARDS, supra, at 166. However, this is only one half of the rationale for exempting speech from governmental abridgment. The right to conscience only undergirds the protection we extend to speech that is related to matters of individual self-definition as in, for example, our choice of religious convictions and conceptions of our individual good. We do not protect political speech principally in order to sustain the liberties of individual conscience, but rather in order to sustain our liberties as citizens to deliberate in common about the shared goods of association. Richards' reduction of the foundation of the free speech principle to the "inalienable right to conscience," see Richards, supra note 4, at $1892-93,1896$, is based on an underestimation of the force of Meiklejohn's argument from democracy and on a contestable neo-Kantian conception of the person.

27. In this respect Robert Bork's conclusion that only explicitly political forms of speech are entitled to First Amendment protection should not be regarded as an eccentric development of Meiklejohn's own views; it is in some ways the most natural implication to draw from Meiklejohn's starting-point. See Bork, Neutral Principles and Some First Amendment Problems, 47 IND. L.J. 1, 27-29 (1971).

28. Meiklejohn, supra note 10 , at 256 .

29. See Bork, supra note 27, at 27. 
duct) constitutive of these experiences and relationships from governmental regulation. ${ }^{30}$

The problem with Meiklejohn's broadly defined political criterion, however, is not merely that it is overinclusive. More importantly, this model of justification misconceives the grounds for affording protection to forms of expression such as art, philosophy, and literature. We do not want to shield them from governmental intrusion primarily because they promote our capacity to participate in political discussion, but because they raise issues concerning cognitive, moral, and aesthetic values whose resolution is best left to our own independent deliberation and judgment, free from the dictates of governmental authority.

The unimpeded discussion of artistic, ethical, religious, and personal ideals (including sexual matters) is primarily valued not as a means or preparation for deliberation about the common political good, but as something directly relevant for the determination of our own respective individual goods, as the medium in which we articulate, promote, defend, and criticize those values and ideals that define who we are and what we care about as individuals. The aim in asserting the exemption of this discourse from the intrusion of governmental authority is not to secure the independence of citizens as rulers of the polity, but rather the independence of citizens as rulers of themselves. That is, it serves to secure their status as persons who can deliberatively define for themselves their ideals and visions of the good through an unrestrained discourse in which such ideals are reciprocally formulated, criticized, and defended by fellow citizens.

\section{A Two-Pronged Model of Speech}

The politically centered account of the foundation of freedom of expression must therefore be expanded to incorporate deliberative discussion about matters that have primarily to do not with how we should collectively govern our community, but rather with how we should individually govern ourselves and our own lives. The end of such discussion is not the well-informed or wise exercise of the political liberties, but the well-

30. Most of the communication constitutive of our primary socialization process and early education would qualify as centrally important in shaping our "sensitivity to human values." Similarly, our expressive involvement in many adult social relationships, whether professional, economic or intimate, also shapes our political attitudes and beliefs, often in quite unforseen and possibly productive ways. Surely the speech connected with such relationships is not protected under the First Amendment merely because it affects our political attitudes.

Meiklejohn's view also faces a special problem with respect to works of art and literature, especially those that aspire to occupy a place in the avant-garde. In view of the way in which our assessment of the value of such works is subject to a continual process of retrospective reassessment, it may be difficult for the Court at any given time to place confidence in its judgment that a given work should be protected because, as Meiklejohn proposes, it promotes "sensitivity to human values." Meiklejohn, supra note 10 , at 256 . 
informed or wise exercise of the liberties of self-definition. ${ }^{31}$ We need a two-pronged model of freedom of expression: One dimension protects explicitly political speech to promote the end of democratic self-government, and the other dimension protects those forms of non-political expression that are directed toward a consideration of the range of values, ideals, and conceptions of the good in terms of which individuals define their sense of themselves and what they are doing with their lives. ${ }^{32}$

It might be thought that this model represents an uneasy compromise between the claims of individual autonomy advanced by the first two approaches to free speech ${ }^{33}$ and the claims of political community advanced by the third. But recall that the problem with the first two accounts, which alternately invoked the concept of negative liberty or positive selfrealization, is that they fail to single out any feature peculiar to speech that would entitle it to special protection. ${ }^{34}$ In contrast, the relation between speech and individual autonomy asserted within the framework of the two-pronged model presented above is based on a necessary connection between freedom of speech and the possibility of what we term deliberative self-definition. The claim is that we can freely and intelligently exercise our freedom of choice on fundamental matters having to do with our own individual ideals and conceptions of the good only if we have access to an unconstrained discussion in which the merits of competing moral, religious, aesthetic, and philosophical values are given a fair opportunity for hearing. The two-pronged model of freedom of expression is not so much distinguished, then, by the opposition between individual and collective autonomy as it is united by the ideal of an unconstrained public discourse which makes possible the deliberative deployment of distinct domains of our liberty.

\section{The Special Status of Speech}

To clarify further how the discourse model answers the question of why speech is entitled to special constitutional protection, it may be instructive

31. These are the liberties through which, in John Rawls' words, we are able to form, revise, and rationally pursue a conception of the good. See Rawls, Justice as Fairness: Political Not Metaphysical, 14 Phil. \& PuB. Afr. 223, 233 (1985).

32. I do not mean to claim that as a matter of fact these two dimensions of freedom of expression function independently of one another, but only that they are analytically distinguishable and that the justification for their constitutional protection rests on different grounds. In the "real world" it is quite clear that they are intimately intertwined (in the same way, for example, that political and moral values are) and that it would be impossible adequately to protect one dimension of speech without at the same time extending considerable protection to the other dimension. A society that maintains strict constraints on the public consideration of different moral points of view is not likely to have a very wide open political debate, and, similarly, prohibiting the advocacy of certain political points of view is likely to have large repercussions on the permissible contours of moral discussion of alternative forms of the good life.

33. See supra text accompanying notes 8-9.

34. See supra text accompanying notes 11-12. For a clear exposition and critique of self-expressivist and self-actualization theories of free speech, see F. Schauer, supra note 15, at 47-58. 
to return to one of the "original sources" of First Amendment theory, namely, Brandeis' concurrence in Whitney $v$. California. ${ }^{35} \mathrm{I}$ shall focus in particular on Robert Bork's interpretation of the famous passage in which Brandeis tries to explain why speech is entitled to special exemption from governmental regulation. Brandeis states:

Those who won our independence believed that the final end of the State was to make men free to develop their faculties; and that in its government the deliberative forces should prevail over the arbitrary. ... They believed that freedom to think as you will and to speak as you think are means indispensable to the discovery and spread of political truth $\ldots$. $^{\text {ss }}$

Bork believes that this passage contains two of the most powerful reasons that Brandeis identifies to justify the extension of special constitutional protection to speech: (1) its contribution to developing the faculties of the individual, and (2) its advancement of the discovery and spread of political truth. ${ }^{37}$ But he argues that closer scrutiny of the first reason reveals that it fails to specify anything peculiar to speech. There are many activities that contribute to the development of our faculties, and speech is not unique in this respect. Bork therefore concludes, following Meikelejohn, that only the second reason provides a defensible rationale for extending special constitutional protection to speech.

But Bork is careless in his reading of Brandeis here. The benefit to which speech is alleged to contribute is not the development of one's faculties as such, but rather "making men free to develop their faculties."38 This difference is significant because it indicates that the link to which Brandeis is attending is not between speech and self-development, but between speech and the possibility of what we have termed deliberative selfdefinition. Talking and listening to others allows us to weigh the value and merits of rival forms of life and conceptions of the good, and thus it makes possible a considered exploration of the range of valuative alternatives. Through discourse with others we can situate ourselves within the horizon of competing values and thus deliberatively choose how we want to deploy our faculties. This ultimately requires us to define what kind of life we want to live, what types of activities we want to attach value to, and what sort of persons we want to be. Speaking with others about their

35. 274 U.S. 357 (1927) (Brandeis, J., concurring).

36. Id. at 375 .

37. Bork, supra note 27, at 25-26. Bork also takes notice of two other benefits of speech identified by Brandeis as grounds for its protection: (1) its contribution to our happiness in engaging in activities, and (2) its function as a safety valve for society. Bork argues that neither of these suffices as a reason to reserve special constitutional protection for speech. There is not space here to pursue this aspect of Bork's critical treatment of Brandeis.

38. Schauer also fails to notice this crucial difference in appealing to Bork's argument in support of his own critique of self-development theorists. See Schauer, supra note 12, at 1292-93. 
rival values and ideals is thus constitutively linked to the possibility of an individual agent exercising a deliberative choice of how she wants to live.

Possessing the freedom to develop one's faculties entails seeing the question of which faculties to develop within a horizon of possible alternative forms of life and values. It demands that one be able to raise the question, for example, of whether to cultivate one's acumen in effecting profitable market exchanges, or in solving problems in scientific research, or in combating social injustice by engaging in political organizing. Only through discourse with others do we acquire the capacity to deliberate about the deployment of our faculties in a way that situates their respective claims to worthiness within a horizon of possible valuative alternatives. At least in this respect, then, speech is indeed significantly different from other social activities whose main purpose is not communicative, ${ }^{38}$ for the latter do not contain within themselves the possibility of surveying the alternatives. Furthermore, it is arguable that this connection between speech and the development of the freedom to define or situate oneself within a range of possible human values by itself yields powerful grounds for protecting freedom of expression from governmental intrusion. We can secure our capacity "freely to develop our faculties" as we see fit (that is, to define ourselves deliberatively) only by assuring the possibility of access to an unrestricted public discussion, in which all the different forms of life, ideals and conceptions of the good current in our culture receive a fair hearing. ${ }^{40}$

\section{ApPlication of THE Theory}

This Section develops the implications of the discourse model presented in Section II for the Supreme Court's approach to First Amendment adjudication. It first sets out the types of considerations this model identifies as central for the analysis of free speech problems. Second, it aims to clarify the significance of this framework by assessing the soundness of the Court's reasoning in two recent cases. The discussion begins with a critical analysis of the Court's treatment of restrictions on corporate speech in First National Bank of Boston v. Bellotti, ${ }^{41}$ and then turns to the Court's review of state-compelled speech in Pacific Gas and Electric Co. v. Public Utilities Commission of California. ${ }^{42}$

39. Bork's examples include trading on the stock market, playing tennis, working as a barmaid, engaging in sexual activity, and pursuing one's profession as a river port pilot.

40. In this sense both levels of discourse we have specified share a common presupposition: namely, that our own choice-whether as a political community deciding matters of public palicy or as particular persons defining our ideals or values-cannot count as rationally justified unless it is exercised on the basis of reasons that are defensible in light of a consideration of all the relevant alternatives.

41. 435 U.S. 765 (1977).

42. 475 U.S. 1 (1986). 


\section{A. General Considerations}

If one starts from the primacy of the discourse model of free speech, it is apparent that an assessment of the scope of free speech rights in a given expressive context must take account of at least two different types of interests: (1) the interests of speakers to participate in the discourse, thereby promoting those beliefs or points of view that they wish to share with a larger audience, and (2) the interests of the audience to hear all the relevant positions represented in the discussion, so that they can make an informed decision concerning the matters which they are called upon to judge. ${ }^{43}$

Since the discourse model views speech within an essentially public framework of communication in which individuals are deliberating about common political goods or matters of individual self-definition, audience interests must be accorded a substantial (though by no means exclusive) amount of weight in fixing the boundaries of free speech rights. ${ }^{44}$ The chief function of protecting speech is to promote agents' deliberative autonomy (on both the collective and individual level) and not to further their interests in either self-expression or self-development for its own sake. It follows, then, that those who take part in this discourse have a crucial interest in hearing a diversity of viewpoints on the issues that come under discussion; only in this way will they be in a position freely to consider the supporting reasons underlying the relevant alternatives.

Contrary to the traditional individualistic conception, the scope of free speech rights cannot be adequately specified by considering their effects only upon individuals' interests in participating in discussion. If one treats these interests as absolute (as is characteristic of the traditional view) $)^{\mathbf{4 5}}$ and asserts that each individual has an unconditional right to express his views to the larger audience, it may well be that in certain situations audience interests in hearing a diversity of viewpoints will be sacrificed and

43. The general role of participant and audience interests in defining the range of free speech rights has been explored in some detail by T.M. Scanlon in Scanlon, Freedom of Expression and Categories of Expression, 40 U. PITT. L. REv. 519, 521-27 (1979). Although his focus tends to be considerably narrower, D.A.J. Richards also discusses the reciprocal interplay between speaker and audience rights in D.A.J. RICHARDS, supra note 26 , at $170-71$. Richards is concerned mainly with the rights (and not interests) of speakers to reach audiences of their choice and the rights of audiences to hear speakers of their choice. The role of audience interests in Scanlon's (and Meiklejohn's) conception is far more comprehensive. It takes into account the audience's interest in hearing a diversity of views that will promote its deliberative autonomy, including views of which the audience may not be aware or which it may prefer not to hear.

44. Audience interests must not be accorded exclusive weight here. It is clear that a concern for deliberative autonomy entails not merely that we have the chance to listen to a diversity of views, but also that we have the opportunity actively to participate in critical discussion of these views. See Buchanan, Autonomy and Categories of Expression: A Reply To Professor Scanlon, 40 U. PITT. L. REV. 551, 553 (1979).

45. The first and second approaches identified in Section I would qualify as traditional views, although as noted some versions of the self-realization approach accord weight to listener as well as participant interests. See Redish, Self-Realization, Democracy and Freedom of Expression: A Reply to Professor Baker, 130 U. PA. L. REv. 678, 679 (1982). 
thus the fundamental purpose of free speech will be frustrated. This is especially the case in situations in which the public space of discourse is marked by a condition of scarcity, so that not all prospective participants can be accommodated within the framework of a discussion marked by limitations of time and audience attention span. Under such circumstances some source of authority must determine which speakers should be allowed to express their views (and which should be excluded), and it would be a perversion of the idea of free speech to claim that speakers who are given an opportunity to speak because they are articulate spokesmen for unrepresented viewpoints thereby violate the free speech rights of those who have necessarily been overlooked. ${ }^{46}$

This perspective on the problem of free speech is, of course, not entirely unfamiliar to the Court. It has made its way into the reasoning of the majority opinion in cases like Lamont v. Postmaster General, in which the Court declared a right not merely to distribute political literature but also to receive it. ${ }^{47}$ It played an even more prominent role in Red Lion Broadcasting Co. v. FCC, in which the Court emphasized the priority of the rights of viewers and listeners over those of broadcasters and insisted that "[i]t is the purpose of the First Amendment to preserve an uninhibited marketplace of ideas in which truth will ultimately prevail, rather than to countenance monopolization of that market, whether it be by the Government itself or a private licensee." 48

Nonetheless, the Court has been reluctant to apply this model systematically to all cases of public speech and has instead restricted it to the special technological circumstances of the broadcasting media, that is, scarcity of broadcast frequencies. From the vantage point of the discourse model, however, such a systemic approach, which defines the scope of free speech rights in relation to the way they affect relevant participant and audience interests, is justified in all cases involving discourse about public matters and not just in the special instances of television and radio broadcasting. The discourse model requires balancing audience and participant interests in specifying the range of free speech rights because only in this way can the key function of protecting speech-namely, promoting agents' capacity for deliberative choice-be adequately secured.

The Court has also been relatively insensitive to the question of how to decide when it is important to be solicitous of audience interests and when participant interests must take priority. From the standpoint of the dis-

46. It is arguable that the idea of free speech itself (and not merely the idea of equality) requires that some principle of selection, sensitive to audience interests, be employed in allocating opportunities to speak. From the standpoint of the discourse model, the failure to do so, in the name of sustaining unconditional participant rights, would undermine the very point of protecting speech. As Meiklejohn correctly observes, in public debate "[w]hat is essential is not that everyone speak, but that everything worth saying shall be said." A. Meiklejohn, Polrtical Frendom, supra note 1, at 26.

47. 381 U.S. 301,308 (1965).

48. 395 U.S. 367,390 (1969). 
course model, audience interests must be given preeminent weight in cases of explicitly political debate because the paramount concern here is that citizens be able to make wise, well-informed choices about matters of shared public concern. Hence, regulation of the exercise of participant rights, through policies such as the fairness doctrine, state subsidies for under-represented speech, or restrictions on individual as well as corporate expenditures, might well be consistent with (if not mandated by) the requirements of the First Amendment. The presumption is that (1) the fundamental consideration in this domain is to enable citizens to make the most intelligent choices possible concerning matters of collective selfgovernance, and (2) this end is best promoted by ensuring consideration of the spectrum of alternative points of view on issues of public dispute.

As argued in Section II, however, the grounds for protecting nonpolitical speech diverge from those underpinning political speech. The end of non-political discourse is primarily to promote the deliberative possibility of individual self-definition and not collective self-governance. This implies that in the non-political sphere-that is, in discussion concerning moral, aesthetic, or religious values or ideals-participant interests must be accorded greater weight in defining the scope of free speech rights. The two-pronged discourse model indicates that in the framework of this sort of discussion participants are engaged primarily in the deliberative process of individual self-definition. For this reason the actual exercise of their right to participate (as opposed to their right to hear a spectrum of views) possesses a centrality greater than that involved in a discussion about the common good. ${ }^{49}$ Agents within this type of discourse are trying to clarify the constitutive features of their own identities, and the opportunity genuinely to participate in a discourse-that is, to take on an "articulate" identity and defend it against challenge by others-marks one crucial way in which individuals are able to delineate and modify their selfconceptions.

\section{B. The Court's Treatment of Restricted and Compelled Speech}

In First National Bank of Boston v. Bellotti, ${ }^{\text {s0 }}$ the Court evaluated the constitutionality of a state statute that prohibited banks and business corporations from making certain expenditures designed to influence the vote on referendum proposals, in particular on a proposal to amend the state

49. To be sure, this can at best serve only as a relative distinction. We can imagine many cases in which audience interests outweigh participant interests even in areas as ostensibly non-political as aesthetic expression. Consider, for example, a government attempt to suppress the works of a small but important group of avant-garde painters. Surely we would view this as a more serious abridgment of freedom of expression than the state's refusal to issue a permit allowing a large number of painting afficionados from a local YMCA to exhibit their sketches on a well-trafficked street in an urban center, despite the fact that in the latter case a greater number of rights to participant expression might be harmed.

50. 435 U.S. 765 (1978). 
constitution to authorize a graduated individual income tax. The Court ruled that the prohibition of corporate expenditures related to the referendum proposal abridged the corporation's First Amendment right to participate in public discussion of governmental affairs and was for this reason unconstitutional.

What is perhaps most conspicuous about Justice Powell's majority opinion in Bellotti is the rather selective (and ultimately arbitrary) use the Court makes of the concept of the priority of audience interests in affording First Amendment protection to corporate speech while denying the state legislature the authority to limit corporate expenditures in order to promote a broader spectrum of public debate. From the vantage point of a discourse theory of speech, the Court's reasoning in Bellotti is strikingly inconsistent: It invokes the contribution to public debate standard in extending protection to corporate speech, but is utterly indifferent to this standard in weighing the rationale for the state statute limiting corporate expenditures.

In evaluating the extent to which corporate speech is entitled to First Amendment protection, the majority opinion in Bellotti is entirely oriented to an audience interest criterion. The question is whether the speech makes a significant contribution to public debate. ${ }^{51}$ This orientation is eminently well-justified. When speech is addressed to the public in the context of political debate, the preeminent consideration is that all the relevant viewpoints receive a fair hearing and not that each participant exercise his opportunity to speak. ${ }^{62}$ Indeed, the Court leaves open the possibility that the participant rights of corporations in exercising their First Amendment liberties may not be as extensive as those pertaining to individuals, for corporations do not have the same interest in self-expression as individuals. ${ }^{53}$ Within the framework of the controversy at issue in Bellotti, however, this does not matter. For if speech is addressed to a public discussion of political issues and has informative value (i.e., satisfies audience interests), this by itself assures the speech of a prima facie claim to First Amendment protection.

In assessing the First Amendment claims of corporate speech, then, the

51. As Justice Powell puts it, the issue is "[t]he inherent worth of the speech in terms of its capacity for informing the public." Id. at 777.

52. The Court itself appears to recognize this by emphasizing that in this context it is a mistake to focus on the source of the speech-the corporation-in evaluating whether its speech warrants protection.

It is interesting that in criticizing the Bellotti decision C. Edwin Baker focuses on precisely this issue-namely, the source of the speech-and argues that corporate speech "should not be protected, because these communications do not derive from the values or political commitments of any individuals." Baker, Realizing Self-Realization: Corporate Political Expenditures and Redish's The Value of Free Speech, 130 U. PA. L. REv. 646, 652 (1982). This follows from Baker's view that only those expressive activities that directly promote the self-realization of individuals should be protected. For Redish's critical response which invokes an audience interest standard within the context of a selfrealization approach, see Redish, supra note 45 , at 679 .

53. 435 U.S. at $777 \&$ n.13. 
majority adheres to a standard that corresponds roughly to that recommended by the discourse model. ${ }^{54}$ Where Justice Powell goes awry is in his countervailing assessment of the interests of the state in restricting corporate expenditures on speech. Precisely the same First Amendment consideration-namely, concern for audience interests in hearing a diversity of viewpoints-might well justify the legislative restriction on corporate expenditures for speech. The function of the state statute is to limit the participant rights of the corporation by not allowing it to spend money on advertising in order to ensure that the other voices in the debate will have sufficient room in the space of public discourse to receive a fair hearing. ${ }^{\mathrm{b5}}$ In this sense the legislature's statute might be likened in function to the rule of a moderator at a town meeting, who is guided in his selection of speakers by the goal of maximizing the diversity of points of view. ${ }^{56}$

Justice Powell never clearly acknowledges that the First Amendment considerations justifying the imposition of restrictions on corporate expenditures for speech stand on exactly the same footing as the considerations justifying its protection-namely, the promotion of audience interests in hearing the relevant positions articulated in debate. In characterizing the state's concerns in restricting corporate expenditures for speech, he focuses instead on "sustaining the active role of the individual citizen in the electoral process and thereby preventing diminution of the citizen's confidence in government." ${ }^{37}$ In this description Powell only obliquely touches on the legitimate First Amendment audience interests that motivate the statute. At a later point Powell comes closer to the real matter at issue by alluding to appellee's argument that "corporations are wealthy and powerful and their views may drown out other points of view."'s8 Nonetheless, he quickly dismisses the force of this argument by insisting that this concern could justify restricting corporate advocacy only if it "threatened imminently to undermine democratic processes." ell's own premises, however, this requirement is far too strong. The state should only have the burden of showing that the audience interests that justify protecting this advocacy are weaker than those warranting its regulation.

54. In this connection, see id. at $782 \mathrm{n.18}$, where Justice Powell appeals to the interest of voters in Massachusetts, "who would be as interested in hearing appellants" views on a graduated tax as the views of media corporations that might be less knowledgeable on the subject."

55. As Justice White correctly points out in his dissent, the statute will not have the effect of climinating the corporation's point of view from public discussion, since individual officers, directors, and stockholders remain free to publicize these views at their own expense. The point is only to ensure that opposing points of view also have sufficient opportunity to reach the attention of the public. Id. at 808-09 (White, J., dissenting).

56. In this connection, see Harry Kalven's contrast between regulations such as Robert's Rules of Order and content regulation in Kalven, The Concept of the Public Forum: Cox v. Lauisiana, 1965 Sur. CT. Rev. 1, 23.

57. 435 U.S. at 787 .

58. Id. at 789.

59. Id. (emphasis added). 
Perhaps because he is aware of this flaw in his argument Powell finds it necessary to butress the authority of his decision by invoking the socalled Buckley dictum that "the concept that government may restrict the speech of some . . . in order to enhance the relative voice of others is wholly foreign to the First Amendment $\ldots .{ }^{60}$ Powell's appeal to this dictum is particularly ironic in view of his own starting point in Bellotti. For the Buckley dictum treats the speaker's participant rights as absolute, immune from government qualification in light of competing First Amendment audience interests that might favor a more diverse regime of speaker participation.

The idea of fixed and absolute participant rights did not inform Powell's treatment of corporate speech at the outset, and his recourse to the Buckley dictum in concluding his decision reflects a curious reversal of field. This reversal is made possible by the failure to recognize that audience interests must assume priority in fixing the scope of free speech rights in political debate and that the unconditional claims made on behalf of speakers' participant rights simply do not make sense in this sphere of discourse. If the Court had possessed a clearer grasp of the proper place of audience interests in defining the scope of participant rights in political debate (as elaborated in the discourse model), it might not have been so easy for it to deploy this concept with the striking inconsistency that characterizes its reasoning in Bellotti.

In the Pacific Gas case we can detect a similar failure on the part of the Supreme Court to exercise sufficient care in applying distinct standards of First Amendment adjudication to specific contexts of discourse. At issue in this case is the constitutionality of a requirement of the California Public Utilities Commission that four times a year a privately owned utility company include in its billing envelopes the speech of a public interest group with which the company disagrees. The private utility company, Pacific Gas, had distributed to its customers over a period of sixty-two years a newsletter in its monthly billing envelopes, and the state utility commission determined that requiring Pacific Gas to distribute the message of an alternative citizens' group four times a year would benefit the interests of its customers by exposing them to a variety of views on public utility issues.

The central question posed by this case is whether compelling Pacific Gas to disseminate the message of a group whose views it does not endorse is a sufficiently serious infringement of its First Amendment rights to make the Commission's requirement unconstitutional. It is significant that in taking up this question the Court starts from the same premise that it advanced in Bellotti: namely, that the corporate speech of Pacific Gas is itself entitled to First Amendment protection because it promotes

60. Id. at 790-91 (quoting Buckley v. Valeo, 424 U.S. 1, $48-49$ (1976)). 
audience interests by contributing to the "'discussion, debate, and the dissemination of information and ideas' that the First Amendment seeks to foster." ${ }^{\text {"61 }}$ Just as in Bellotti, however, the Court underplays the extent to which it is exactly the same First Amendment considerations that provide the underlying rationale for granting the citizens' group, TURN, periodic access to Pacific Gas' billing envelopes.

Instead of engaging in a balancing of First Amendment harms and benefits that are implied by conceding TURN occasional access to Pacific Gas' envelopes, the Court focuses exclusively on the harms or "burdens" to Pacific Gas' First Amendment participant rights that are imposed by compelling access. The harms to Pacific Gas' rights are threefold: (1) It forfeits its right not to speak, because it will have to respond to TURN's claims; (2) It is compelled to serve as a means for disseminating views with which it does not agree; and (3) It suffers forced public identification with beliefs to which it does not actually subscribe. Even if one concedes that these impositions represent genuine burdens on Pacific Gas' exercise of its First Amendment rights, they must be weighed against the promotion of First Amendment interests served by granting TURN periodic access to Pacific Gas' customers.

But the real problem with Justice Powell's majority opinion lies at a deeper level. The Court is employing a model of First Amendment harms here that makes sense within the context of non-political discourse related to what we termed the liberties of self-definition, but not with regard to debate about matters of general political interest. The negative free speech rights not to speak and not to associate oneself with repugnant beliefs have paradigmatic application in self-definitional discourse because here agents are concerned with identifying those values and ideals that correspond to their sense of who they truly are as individuals and what they stand for. Compelling them to speak or to associate with beliefs they do not hold constitutes a basic violation of their fundamental liberties of thought and conscience. ${ }^{62}$

It is for this reason that Powell must repeatedly invoke the precedents of West Virginia State Board of Education v. Barnette ${ }^{63}$ and Wooley $v$. Maynard ${ }^{64}$ in support of his opinion. Both of these cases involved state regulations in which individuals were forced to associate with views that sharply violated their fundamental religious convictions. In the context of corporate speech addressed to political debate, however, these precedents lose equivalent force. What is primarily at stake in political debate is not the individual's aim to clarify and affirm the basic terms of his identity, but the community's ambition to choose the wisest, most prudent policies.

61. 475 U.S. 1, 8 (1986) (quoting Bellotti, 435 U.S. at 783).

62. See id. at 32-33 (Rehnquist, J., dissenting).

63. 319 U.S. 624 (1943).

64. 430 U.S. 705 (1977); see also supra note 8. 
Does Pacific Gas really have a fundamental constitutional right to remain silent in the course of a debate in which it has been the sole voice addressing its customers for sixty-two years and has a monopoly on the means of access to its audience? Does it suffer from public identification with beliefs that it does not hold when it is given ample opportunity to include a disclaimer in its billing envelops distinguishing its own views on public issues from those of TURN? Finally, are its constitutional rights truly compromised by serving as an occasional vehicle for the distribution of views it does not endorse when it owes its own First Amendment protection to its promotion of the very same interests that would also be served by granting periodic access to TURN? To respond affirmatively to these questions is to extend the concept of negative free speech rights beyond the domain of its proper application.

\section{CONCLUSION}

The analysis of Bellotti and Pacific Gas indicates that what is missing from the Court's reasoning is sufficient consideration of the limited contexts in which its application of specific elements of First Amendment doctrine is justified. As we have seen, the assorted doctrinal claims deployed by the Court range from an assertion of the centrality of speech for democratic self-government to an insistence upon the primacy of negative free speech rights to an affirmation of the unabridgeable status of participant rights. The Court's employment of such doctrine is vitiated by its failure to clarify the relationship between the paradigmatic contexts in which the application of specific doctrine may be warranted and the particular circumstances of adjudication in which such doctrine is actually invoked. Closer attention to the contexts of adjudication would demonstrate that the appeal to such rigid doctrines is one-sided and in some cases (for example, Pacific Gas) entirely inappropriate, because the categories of expression and the relevant interests involved in these cases require doctrines of a quite different sort. Until the Court makes a more systematic effort to relate its use of free speech doctrine to the actual categories of expression (political, moral, personal and aesthetic) in which free speech is exercised and to the relevant range of interests involved within each of these different categories, it will be unable to dispel the impression that its use of such doctrine serves the end of selective rationalization rather than reasoned judgment. 